\title{
Camel Myoglobin
}

\author{
By E. S. AWAD AND L. KOTITE \\ Department of Chemistry, American University of Beirut, Beirut, Lebanon
}

(Received 20 August 1965)

\begin{abstract}
1. Crystalline myoglobin was prepared from camel heart muscle. 2. A method was developed for the isolation of myoglobin that employs molecular-sieve chromatography. 3. Analytical chromatography of the camel myoglobin on a molecular-sieve column and on two types of ion-exchange columns gave in each case a single elution band, which accounted for better than $98 \%$ recovery and showed that the product was free from haemoglobin. 4. The iron content on a dry weight basis was $0.308 \%$. This value corresponds to a molecular weight of 18100 . 5. The spectra of acidic ferrimyoglobin, basic ferrimyoglobin and ferrimyoglobin cyanide were measured. 6. The $\mathrm{p} K_{a}$ of the dissociation of the haem-bound water molecule in acidic ferrimyoglobin was 8.53 at $25^{\circ}$. 7. Conclusions are drawn about the charge on the surface of the camel ferrimyoglobin molecule as compared with horse and sperm-whale ferrimyoglobins.
\end{abstract}

The procedures that have been used by different investigators for the preparation of crystalline myoglobin vary in details, but in principle consist in extraction of myoglobin from the minced muscle with water and subsequent fractionation with ammonium sulphate between $80 \%$ and $100 \%$ saturation at $\mathrm{pH}$ close to 7 .

Crystalline myoglobin has been prepared from horse (Theorell, 1932; Roche \& Vieil, 1940; Kendrew, 1950; Lawrie, 1951; Kendrew \& Trotter, 1954), cow (Roche, Derrien \& Vieil, 1942; RossiFanelli, Cavallini \& De Marco, 1954; Lewis \& Schweigert, 1955), man (Drabkin, 1945; Theorell \& de Duve, 1947; Rossi-Fanelli, 1948; Rossi-Fanelli et al. 1954; Luginbuhl, 1960), whale (Keilin \& Schmid, 1948; Kendrew, Parrish, Marrack \& Orlans, 1954; Kendrew \& Pauling, 1956; Kendrew \& Parrish, 1957 ; Bradley, 1959), sheep (Beznak, 1948), turtle (Renard, 1953), carp (Hamoir, 1953), seal, penguin, porpoise, California sea lion and dolphin (Kendrew et al. 1954), tunny (Huys, 1954; RossiFanelli \& Antonini, 1955; Matsuura \& Hashimoto, 1955) and molluscs (Rossi-Fanelli, Antonini \& Povoledo, 1957).

Haemoglobin is a natural contaminant in the preparation of myoglobin. After the discovery that hremoglobin is insoluble whereas myoglobin is soluble in 3M-phosphate at pH 6.6 (Morgan, 1936), this difference in solubility has been used for the purification of myoglobin. Myoglobin can be separated conveniently from haemoglobin by chromatography on molecular-sieve columns (Awad, Cameron \& Kotite, 1963).

Myoglobin has in several instances been shown to be microheterogeneous. For example, subcomponents of myoglobins of the following species have been resolved by ion-exchange chromatography or by electrophoresis: horse (Boardman \& Adair, 1956; Åkeson \& Theorell, 1960; Reichlin, Hay \& Levine, 1963), man (Rossi-Fanelli \& Antonini, 1957 ; Perkoff, Hill, Brown \& Tyler, 1962), seal (Rumen, 1959), tunny (Brown, 1961) and sperm whale (Edmundson \& Hirs, 1962; Atassi, 1964).

The present work describes the isolation of myoglobin from camel (Camelus dromedarius) heart muscle by using molecular-sieve chromatography. The product, ferrimyoglobin, was crystallized from ammonium sulphate solution and some of its physical properties were investigated.

\section{MATERIALS}

Whatman CM 70 powder (CM-cellulose cation-exchanger) was obtained from W. and R. Balston Ltd., London.

Sephadex G-75 [bead form, fine grade (polydextran molecular sieve of nominal exclusion limit 50000 mol.wt.)], CM-Sephadex C-50 [fine grade (carboxymethyl-polydextran cation-exchanger)] and SE-Sephadex C-50 [fine grade (sulphonylethyl-polydextran cation-exchanger)] were obtained from Pharmacia, Uppsala, Sweden.

Sperm-whale ferrimyoglobin and horse ferrimyoglobin were obtained as salt-free freeze-dried powders from Seravac Laboratories, Maidenhead, Berks.

All other chemicals were of A.R. grade and distilled deionized water was used throughout.

\section{METHODS}

Extinction was measured with a Zeiss PMQII spectrophotometer. Silica cells of $1 \mathrm{~cm}$. light-path were used. 
Measurement of $\mathrm{pH}$ was made with a Radiometer model 4 pH-meter, with glass and calomel electrodes. The instrument was standardized at $25^{\circ}$ against phosphate buffer, pH6.865 (Bates, 1964).

Centrifugation was performed at $4^{\circ}$ in a refrigerated MSE centrifuge.

A Cahn electro-microbalance was used for weighing milligram quantities of myoglobin for iron analysis.

All operations in the preparation of myoglobin were carried out in a cold room at $4^{\circ}$.

Molecular-sieve and ion-exchange chromatography were carried out in a cold room at $4^{\circ}$ by using standard techniques (Boardman \& Partridge, 1955; Porath, 1962).

Iron analysis was performed on $2-8 \mathrm{mg}$. samples of myoglobin, dried at $110^{\circ}$, by digestion in an $\mathrm{HClO}_{4}-\mathrm{H}_{2} \mathrm{O}_{2}$ medium, reduction of the iron with hydroxylamine hydrochloride and colorimetric assay with $o$-phenanthroline (Cameron, 1965; Hanania, Yeghiayan \& Cameron, 1966).

Myoglobin spectra were measured as follows. A stock solution was prepared by dissolving $80 \mathrm{mg}$. of salt-free freeze-dried myoglobin in $5 \mathrm{ml}$. of distilled water and filtering. (No significant amount of sediment remained on the filter paper, which indicated the absence of denatured material.) (a) Acidic ferrimyoglobin spectrum. A $1.00 \mathrm{ml}$. portion of the stock solution of myoglobin was diluted to $10.0 \mathrm{ml}$. with $0.05 \mathrm{M}$-phosphate buffer, $\mathrm{pH} 6.2$, and the extinction was measured at wavelengths between 450 and $700 \mathrm{~m} \mu$ against a buffer blank. This solution was diluted further, tenfold, with the same buffer and the extinction was measured at wavelengths between 240 and $450 \mathrm{~m} \mu$. (b) Basic ferrimyoglobin spectrum. The procedure was the same as that used for acidic ferrimyoglobin, except that the buffer was $0.05 \mathrm{~m}$-borate, $\mathrm{pH} 10 \cdot 8$. (c) Ferrimyoglobin cyanide spectrum. Again the procedure was the same, except for the buffer, which was $0.05 \mathrm{~m}$-phosphate, $\mathrm{pH} 7 \cdot 0$, containing $0.05 \%$ of KCN. For each spectrum, over the range 240-700 $\mathrm{m} \mu$, the extinction was measured at about 90 different wavelengths; near the absorption peaks, measurements were made at $2 \mathrm{~m} \mu$ intervals. The iron content of the stock solution of myoglobin was determined as follows. A $0 \cdot 300 \mathrm{ml}$. portion was transferred to a $10 \mathrm{ml}$. volumetric flask and evaporated to near-dryness on a steam bath. The procedure of Cameron (1965) was then used for the digestion of the myoglobin and the colorimetric assay of iron. The molar extinction coefficients, $\epsilon\left(\mathrm{M}^{-1} \mathrm{~cm} .^{-1}\right)$, were calculated on the basis of an $\mathrm{Fe}$ content of $0 \cdot 308 \%$ and $1 \mathrm{Fe}$ atom $/ \mathrm{mol}$. of myoglobin (i.e. a molecular weight of 18100) (see the Results section).

\section{RESULTS}

Preparation of camel myoglobin. Camel hearts were obtained immediately after slaughter and kept in ice. The muscle was dissected free from fatty tissue and ligaments, washed with tap water, drained and stored frozen at $-15^{\circ}$ for up to 10 months. Before use the muscle was thawed overnight at $4^{\circ}$. All operations in the preparation of the myoglobin were carried out in a cold room at $4^{\circ}$.

Step (1): extraction. A $3 \mathrm{~kg}$. sample of camel heart muscle was cut into slices, minced in a meat grinder, suspended in 31. of ice-cold distilled water and stirred slowly for $24 \mathrm{hr}$. in the cold. The mixture was squeezed through cheese-cloth, centrifuged at $3000 \mathrm{rev} . / \mathrm{min}$. $(2400 \mathrm{~g})$ for $2 \mathrm{hr}$. and filtered through Whatman no. 1 fluted filter paper. The $\mathrm{pH}$ of the filtrate was $6 \cdot 4$.

Step (2): concentration of myoglobin solution. The filtrate was dialysed extensively against distilled water and twice against $0.01 \mathrm{~m}$-phosphate

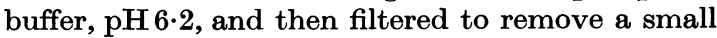
amount of sediment. The filtrate $(3430 \mathrm{ml}$.) was allowed to percolate through a Whatman CM 70 (CM-cellulose) column $(2.5 \mathrm{~cm}$. diam. $\times 30 \mathrm{~cm}$.) preequilibrated with 0.01 M-phosphate buffer, pH6.2. In this operation the myoglobin and some haemoglobin were adsorbed in a band at the top of the column. After a brief washing with $0.01 \mathrm{M}$ phosphate buffer, $\mathrm{pH} 6 \cdot 2$, the band containing myoglobin was eluted from the column with $0 \cdot 1 \mathrm{M}$ phosphate buffer, $\mathrm{pH} 7 \cdot 3$. A cut of the effluent $(290 \mathrm{ml}$.) that contained the myoglobin was taken. About tenfold concentration of the original myoglobin extract was thereby achieved. The $E_{410} / E_{280}$ extinction ratio was $\mathbf{1 . 9 2}$.

Step (3): chromatography on Sephadex G-75. The cut containing myoglobin was applied to a column $(5 \mathrm{~cm}$. diam. $\times 80 \mathrm{~cm}$.) of Sephadex G-75,

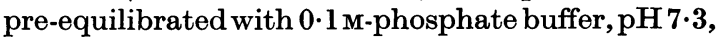
and was eluted with the same buffer. The effluent was collected in $15 \mathrm{ml}$. fractions. The extinction of each fraction was measured at 280 and $410 \mathrm{~m} \mu$. When the effluent was too concentrated to be read in the spectrophotometer, a suitable dilution was made, e.g. $0.10 \mathrm{ml}$. to $5.0 \mathrm{ml}$. The elution profile is shown in Fig. 1 . A cut (315 ml.) was taken by pooling the effluent fractions as indicated in Fig. 1. The $E_{410} / E_{280}$ extinction ratio of the pooled fractions was $4 \cdot 45$.

Step (4): second-cycle chromatography. Steps $(2),(3)$ and again (2) were repeated in succession. A dark-brown solution $(67 \mathrm{ml}$.) of ferrimyoglobin in $0 \cdot 1 \mathrm{~m}$-phosphate buffer, $\mathrm{pH} 7 \cdot 3$, was obtained. The $E_{410} / E_{280}$ extinction ratio was 5.08.

Step (5): freeze-drying. The solution of myoglobin was dialysed exhaustively against distilled deionized water and freeze-dried. The fluffy lightbrown product $\left(0 \cdot 79 \mathrm{~g}\right.$.) was stored at $4^{\circ}$.

Crystallization. Suitable conditions for the crystallization of camel myoglobin were determined by setting up 30 small tubes capped tightly and containing $2 \mathrm{ml}$. of solutions of myoglobin in $75-85 \%$ saturated ammonium sulphate buffered with phosphate at $\mathrm{pH} 6 \cdot 8$. The concentrations of myoglobin, ammonium sulphate and phosphate were varied so that crystallization was attempted under ten different conditions. The tubes were allowed to stand at room temperature $\left(25^{\circ}\right)$ without being disturbed. Crystallization took place within 4 weeks in most of the tubes. The following 


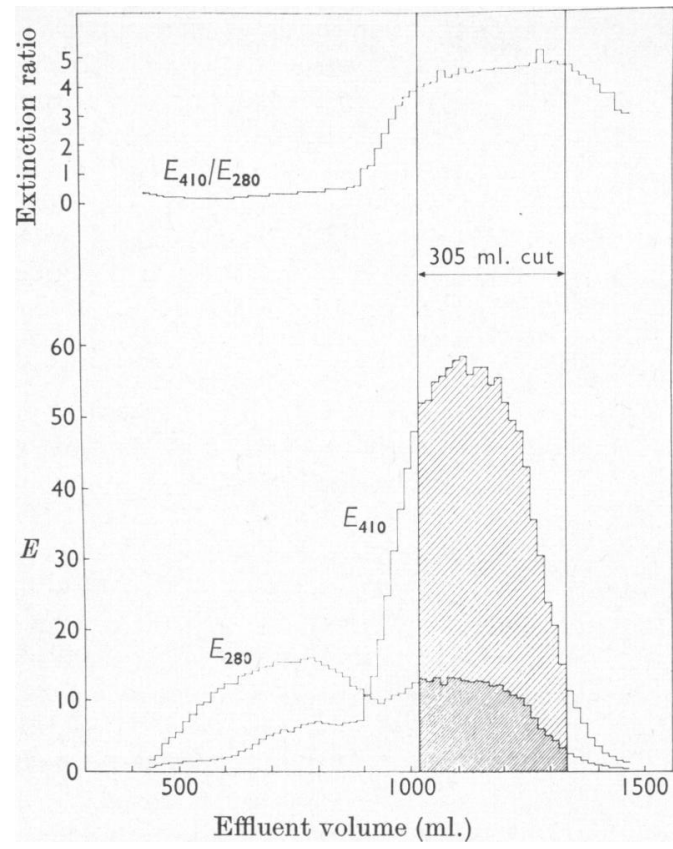

Fig. 1. Elution profile obtained in step (3) in the preparation of camel myoglobin (see the text). A Sephadex G-75 column $(5 \mathrm{~cm}$. diam. $\times 80 \mathrm{~cm}$.) was used, the eluent being $0 \cdot 1$ M-phosphate buffer, pH 7·3.

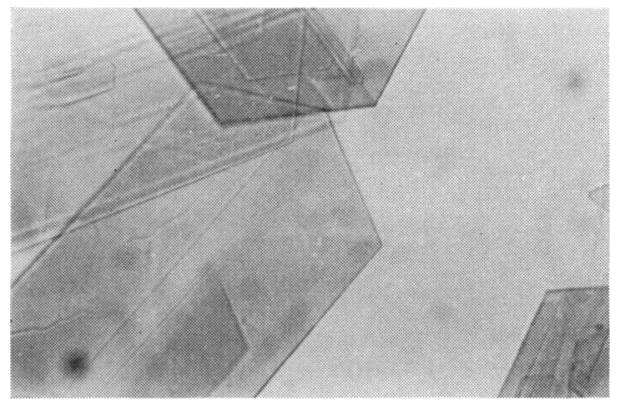

Fig. 2. Camel ferrimyoglobin crystals. Magnification $\times 50$.

procedure was used to crystallize a large amount of myoglobin.

A filtered solution of $0.5 \mathrm{~g}$. of salt-free freeze-dried myoglobin dissolved in $30 \mathrm{ml}$. of distilled water was mixed with a filtered solution of saturated ammonium sulphate-2 M-phosphate buffer, $\mathrm{pH} \mathrm{6.8}$ $(19: 1, \mathrm{v} / \mathrm{v})$. A suspension ( $1 \mathrm{ml}$.) containing seed crystals was added. The mixture was kept in a glass-stoppered flask at $25^{\circ}$ in a thermostatically controlled bath. Crystallization was complete within 4 days.

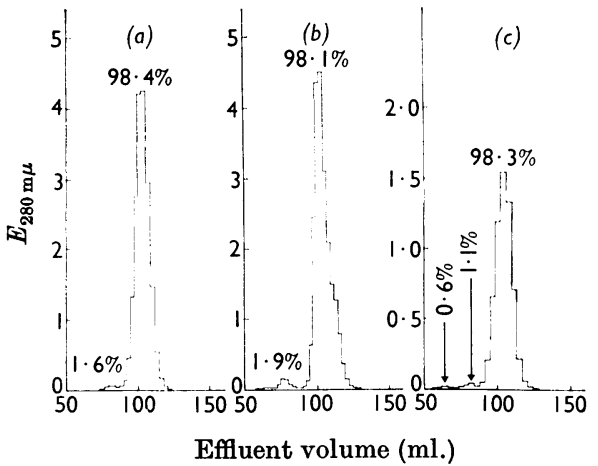

Fig. 3. Chromatographic analysis of camel ferrimyoglobin. (a) Molecular-sieve chromatography on a Sephadex G-75 column $(2.5 \mathrm{~cm}$. diam. $\times 34 \mathrm{~cm}$.), the eluent being $0.05 \mathrm{M}-$ phosphate buffer, $\mathrm{pH} 6 \cdot 84$, and the flow rate $8 \cdot 4 \mathrm{ml} . / \mathrm{hr}$.; the sample contained $40 \mathrm{mg}$. in $1 \mathrm{ml}$. (b) Ion-exchange chromatography on a CM-Sephadex C-50 column $(2 \cdot 5 \mathrm{~cm}$. diam. $\times 29 \mathrm{~cm}$.), the eluent being $0.05 \mathrm{M}$-phosphate buffer, pH 6.85, and the flow rate $9 \cdot 6 \mathrm{ml} . / \mathrm{hr}$.; the sample contained $40 \mathrm{mg}$. in $1 \mathrm{ml}$. (c) Ion-exchange chromatography on an SE-Sephadex C-50 column $(2.5 \mathrm{~cm}$. diam. $\times 28 \mathrm{~cm}$.), the eluent being $0.05 \mathrm{~m}$-phosphate buffer, $\mathrm{pH} 6.82$, and the flow rate $14 \mathrm{ml}$./hr.; the sample contained $20 \mathrm{mg}$. in $1 \mathrm{ml}$.

The crystals were dark brown, the largest approx. $2 \mathrm{~mm} . \times 0.5 \mathrm{~mm} . \times 0.02 \mathrm{~mm}$. A photograph is shown in Fig. 2.

Analytical chromatography. Samples of camel ferrimyoglobin were analysed by molecular-sieve chromatography on Sephadex G-75, the eluent being 0.05 M-phosphate buffer, $\mathrm{pH} 6.84$, and by ion-exchange chromatography on CM-Sephadex C-50, the eluent being 0.05M-phosphate buffer, pH 6.85, and on SE-Sephadex C-50, the eluent being $0.05 \mathrm{M}$-phosphate buffer, $\mathrm{pH} 6.82$. Elution profiles are shown in Fig. 3. In each of the three chromatographic systems, a single elution band was obtained which accounted for at least $98 \%$ recovery. Other runs on columns of SE-Sephadex C-50, the eluents being 0.05 M-phosphate buffer at $\mathrm{pH6} .40$ and at $\mathrm{pH} 7 \cdot 42$, gave similar elution profiles. These results show that no significant amounts of haemoglobin were present, since both the molecular-sieve and ion-exchange chromatography would have resolved any haemoglobin component in the sample. Comparison of the behaviour of camel ferrimyoglobin with horse and sperm-whale ferrimyoglobins in the same ion-exchange chromatographic system indicates that camel and horse ferrimyoglobins are about equally positively charged at $\mathrm{pH} 6 \cdot 85$, whereas sperm-whale ferrimyoglobin is considerably more positively charged. This conclusion is borne out by the data in Table 1. 
Table 1. Elution volumes of ferrimyoglobin of different species chromatographed on CM-Sephadex C-50 with 0.05 м-phosphate buffer, $\mathrm{pH} 6.85$

Samples (40 mg.) of myoglobin dissolved in $1.0 \mathrm{ml}$. of buffer were applied to the column $(2.5 \mathrm{~cm}$. diam. $\times 29 \mathrm{~cm}$.) of CM-Sephadex C-50. The eluent was 0.05 M-phosphate buffer, $\mathrm{pH} 6 \cdot 85$, the flow rate being $9 \cdot 6 \mathrm{ml}$./ $\mathrm{hr}$.

Camel ferrimyoglobin

Horse ferrimyoglobin (major component*)

Elution volume (ml.)

Sperm-whale ferrimyoglobin (major component*)

108

129

520

* Horse and sperm-whale ferrimyoglobins were resolved into one major and several minor components in this chromatographic system (E. S. Awad \& L. Kotite, unpublished work). Edmundson \& Hirs (1962) have resolved sperm-whale myoglobin into five components on Amberlite IRC-50 columns with $0.34 \mathrm{~N}$-sodium citrate- $\mathrm{NaCl}$ buffer, pH5.88.

The analytical chromatography on CM-Sephadex C-50 and on SE-Sephadex C-50 indicates that the sample of camel ferrimyoglobin was microhomogeneous. Sperm-whale and horse ferrimyoglobins were each resolved into at least four sub-components in the same chromatographic systems.

Iron content and molecular weight. Iron analysis was performed on six samples of myoglobin. The analytical results gave an average value of $0.308 \pm$ $0.002 \%$ of iron, which yields a calculated molecular weight of 18100 on the basis of 1 atom of iron $/ \mathrm{mol}$. of myoglobin. The molecular-sieve elution volume, which was obtained in the runs described above, precludes any integral multiple of this molecular weight.

Spectra. The spectra of acidic ferrimyoglobin, basic ferrimyoglobin and ferrimyoglobin cyanide are shown in Fig. 4. Values of the molar extinction coefficients at the maxima, minima and shoulder regions of the spectra are given in Table 2.

Acid dissociation of the haem-bound water molecule. Stock ferrimyoglobin solution (approx. $1 \mathrm{~mm}$ ) was prepared by dissolving $100 \mathrm{mg}$. of saltfree freeze-dried myoglobin in $15 \mathrm{ml}$. of distilled water, adding a few small crystals of sodium nitrite, dialysing twice for $3 \mathrm{hr}$. against distilled water to remove excess of nitrite and filtering. Of this solution $1.00 \mathrm{ml}$. was added to $9.00 \mathrm{ml}$. of buffer of ionic strength 0.05 (phosphate buffer, pH 6.2, glycine buffer, $\mathrm{pH} 11.0$, and ten borate buffers varying in $\mathrm{pH}$ between 8.3 amd 10.6). The $\mathrm{pH}$ of the mixture was measured with an accuracy of $0.002 \mathrm{pH}$ unit and the extinction was determined at $408 \mathrm{~m} \mu$, which is the wavelength of maximum

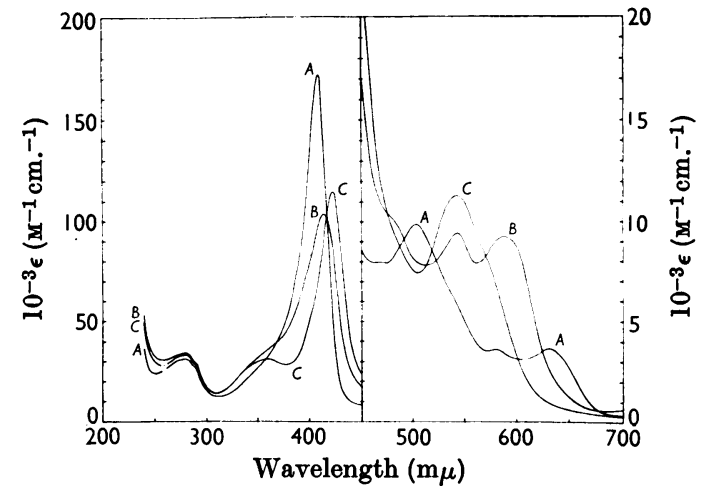

Fig. 4. Spectra of camel myoglobin: $A$, acidic ferrimyoglobin in $0.05 \mathrm{M}$-phosphate buffer, $\mathrm{pH} 6.2 ; B$, basic ferrimyoglobin in $0.05 \mathrm{M}$-borate buffer, $\mathrm{pH} 10.8 ; C$, ferrimyoglobin cyanide in $0.05 \mathrm{~m}$-phosphate buffer, $\mathrm{pH} 7 \cdot 0$, containing $0.05 \%$ of $\mathrm{KCN}$. The spectra were measured at room temperature $\left(25^{\circ}\right)$. Molar extinction coefficients are given in Table 2.

difference in the extinction between the acidic and basic forms of camel ferrimyoglobin.

It was assumed that ferrimyoglobin in the phosphate buffer ( $\mathrm{pH} \mathrm{6.2)} \mathrm{is} \mathrm{entirely} \mathrm{in} \mathrm{the} \mathrm{acidic} \mathrm{form,}$ i.e. $\mathrm{Fe}\left(\mathrm{H}_{2} \mathrm{O}\right)^{+}$, and in the glycine buffer $(\mathrm{pH} 11 \cdot 0)$ entirely in the basic form, i.e. $\mathrm{FeOH}$, whereas in the borate buffers there exists a mixture of acidic and basic forms. The degree of dissociation, $\alpha$, of the haem-bound water molecule, which corresponds to the equilibrium:

$$
\mathrm{Fe}\left(\mathrm{H}_{2} \mathrm{O}\right)^{+} \rightleftharpoons \mathrm{FeOH}+\mathrm{H}^{+}
$$

is given by:

$$
\begin{aligned}
\alpha & =[\mathrm{FeOH}] /\left(\left[\mathrm{Fe}\left(\mathrm{H}_{2} \mathrm{O}\right)^{+}\right]+[\mathrm{FeOH}]\right) \\
& =\left(E_{\text {borate }}-E_{\text {glycine }}\right) /\left(E_{\text {phosphate }}-E_{\text {glyclne }}\right)
\end{aligned}
$$

where $E$ is the extinction of the myoglobin solution at $408 \mathrm{~m} \mu$ and the subscript refers to the buffer in which the extinction was measured. Defining the acid dissociation constant, $K_{a}$, by the equation :

then:

$$
K_{a}=[\mathrm{FeOH}]\left[\mathrm{H}^{+}\right] /\left[\mathrm{Fe}\left(\mathrm{H}_{2} \mathrm{O}\right)^{+}\right]
$$

$$
K_{a}=\alpha\left[\mathrm{H}^{+}\right] /(1-\alpha)
$$

where $\left[\mathrm{H}^{+}\right]$is the activity of $\mathrm{H}^{+}$ion as measured by the glass electrode. Rearrangement of the last equation gives:

$$
\alpha=1-\alpha\left[\mathrm{H}^{+}\right] / K_{a}
$$

It can be shown that $K_{a}$ is given by the intercept on the abscissa of a plot of $\alpha$ against $\alpha\left[\mathrm{H}^{+}\right]$. A typical plot is shown in Fig. 5. The results of four runs gave an average $\mathrm{p} K_{a}$ value of 8.53 at $25^{\circ}$ (average deviation less than \pm 0.005 ). 
Table 2. Spectral characteristic of camel myoglobin

The spectra are given in Fig. 4. $\epsilon$, Molar extinction coefficient $\left(\mathrm{M}^{-1} \mathrm{~cm} . .^{-1}\right)$; (max.), maximum; (min.), minimum; (sh.), shoulder.

Acidic ferrimyoglobin

\begin{tabular}{lc}
\hline$\lambda(\operatorname{m} \mu)$ & $10^{-3} \epsilon$ \\
250 (min.) & $24 \cdot 1$ \\
274 (sh.) & $30 \cdot 8$ \\
280 (max.) & $31 \cdot 3$ \\
290 (sh.) & $26 \cdot 6$ \\
310 (min.) & $12 \cdot 4$ \\
360 (sh.) & $33 \cdot 0$ \\
409 (max.) & $172 \cdot 0$ \\
466 (min.) & $7 \cdot 94$ \\
470 (max.) & $7 \cdot 96$ \\
474 (min.) & $7 \cdot 94$ \\
503 (max.) & $9 \cdot 87$ \\
573 (min.) & $3 \cdot 55$ \\
580 (max.) & $3 \cdot 60$ \\
605 (min.) & $3 \cdot 10$ \\
630 (max.) & $3 \cdot 66$
\end{tabular}

$\epsilon_{410} / \epsilon_{280}=5 \cdot 49$
Basio ferrimyoglobin

\begin{tabular}{lc}
\multicolumn{1}{c}{$\lambda(\mathrm{m} \mu)$} & $10^{-3} \epsilon$ \\
259 (min.) & $30 \cdot 7$ \\
274 (sh.) & $33 \cdot 6$ \\
280 (max.) & $34 \cdot 3$ \\
290 (sh.) & $29 \cdot 3$ \\
308 (min.) & $13 \cdot 7$ \\
360 (sh.) & $36 \cdot 2$ \\
414 (max.) & $104 \cdot 0$ \\
480 (sh.) & $10 \cdot 20$ \\
512 (min.) & $7 \cdot 83$ \\
542 (max.) & $9 \cdot 48$ \\
562 (min.) & 7.93 \\
587 (max.) & 9.30 \\
600 (sh.) & $8 \cdot 65$ \\
680 (min.) & 0.57
\end{tabular}

Ferrimyoglobin cyanide

\begin{tabular}{lc}
\hline \multicolumn{1}{c}{$\lambda(\mathrm{m} \mu)$} & $10^{-3} \epsilon$ \\
257 (min.) & $27 \cdot 7$ \\
274 (sh.) & $32 \cdot 7$ \\
280 (max.) & $33 \cdot 3$ \\
290 (sh.) & $28 \cdot 1$ \\
308 (min.) & 13.7 \\
360 (max.) & $31 \cdot 4$ \\
378 (min.) & 28.7 \\
423 (max.) & $115 \cdot 0$ \\
505 (min.) & $7 \cdot 45$ \\
542 (max.) & $11 \cdot 32$ \\
570 (sh.) & 8.25
\end{tabular}

$\epsilon_{423} / \epsilon_{280}=3 \cdot 46$

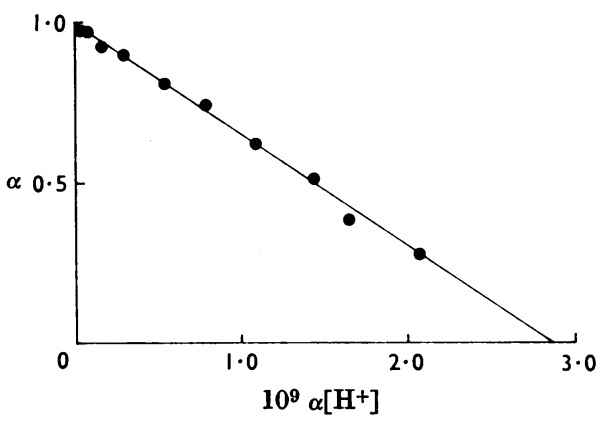

Fig. 5. Example of plot for the determination of $p K_{a}$ of the haem-bound water molecule in camel acidic ferrimyoglobin (see the text). The intercept on the abscissa gives $K_{a} 2 \cdot 88 \times 10^{-9}$, i.e. $\mathrm{p} K_{a} 8 \cdot 54$.

\section{DISCUSSION}

The main advantage of the present procedure for the preparation of myoglobin is the ease and thoroughness with which haemoglobin is removed by use of a molecular-sieve column. Other proteins are either not extracted from the muscle with distilled water in step (1) of the preparation, or are not adsorbed on Whatman CM-cellulose in step (2) and are therefore washed out of the column, or are separated out by the molecular-sieve column in step (3). The identity and purity of the product are established by the spectra, the iron analysis and the analytical chromatography.

The molar extinction coefficient of the protein band in camel acidic ferrimyoglobin, $\epsilon_{280} 31 \cdot 3 \times$ $10^{3} \mathrm{M}^{-1} \mathrm{~cm} .^{-1}$, is very close to the corresponding values for horse acidic ferrimyoglobin $\left(\epsilon_{280} 31 \cdot 3 \times\right.$ $10^{3} \mathrm{M}^{-1} \mathrm{~cm} .-1$; G. I. H. Hanania, personal communication) and for sperm-whale acidic ferrimyoglobin $\left(\epsilon_{280} 31.2 \times 10^{3} \mathrm{M}^{-1} \mathrm{~cm} .^{-1}\right.$; Hanania et al. 1966). The $E_{409} / E_{280}$ extinction ratio for camel acidic ferrimyoglobin is $5 \cdot 49$, higher than the corresponding values of $\mathbf{5 \cdot 1 9}$ for horse acidic ferrimyoglobin (G. I. H. Hanania, personal communication) and 5.03 for sperm-whale acidic ferrimyoglobin (Hanania et al. 1966). This indicates that the electronic distribution in the region of the haem group is different in the myoglobins of these three species.

The $\mathrm{p} K_{a}$ for the ionization of the haem-bound water molecule in camel acidic ferrimyoglobin is 8.53 , lower than that for horse acidic ferrimyoglobin (pK $K_{a} 8.92$ at $20^{\circ}$ and $I 0.08$; George \& Hanania, 1952) and that for sperm-whale acidic ferrimyoglobin ( $\mathrm{p} K_{a} 8.96$ at $25^{\circ}$ and $I 0.05$; G. I. H. Hanania, personal communication). The difference of $0.4 \mathrm{pH}$ unit is beyond experimental error. As a check, we have measured the $\mathrm{p} K_{a}$ values for horse acidic ferrimyoglobin and for sperm-whale acidic ferrimyoglobin, using the same buffer solutions as were used in our measurements of the $\mathrm{p} K_{a}$ of camel acidic ferrimyoglobin. For horse acidic ferrimyoglobin we obtained $\mathrm{p} K_{a} 8.94$ and for spermwhale acidic ferrimyoglobin $p K_{a} 8.97$, in good agreement with the values of Hanania and coworkers. The comparatively low value of the $\mathrm{p} K_{a}$ of the ionization of the water molecule in camel ferrimyoglobin indicates that the local ionic 
environment of the haem group in camel ferrimyoglobin, at about $\mathrm{pH} \mathrm{8.5}$, is more positive than in horse and sperm-whale ferrimyoglobins.

In contrast, camel and horse ferrimyoglobins, at about $\mathrm{pH} 7$, have a smaller overall positive surface charge than sperm-whale ferrimyoglobin, as evidenced by the ion-exchange chromatography.

Such species differences are not unexpected, since there is good reason to believe that the amino acid composition and sequence are not identical for myoglobins of different species.

We thank Dr Usama al-Khalidi, Department of Biochemistry, for his help in obtaining camel hearts and Dr Fuad Farah, Department of Medicine, for taking the photograph of myoglobin crystals. This work was supported by a Faculty of Arts and Sciences Research Grant, American University of Beirut.

\section{REFERENCES}

Åkeson, A. \& Theorell, H. (1960). Arch. Biochem. Biophys. 91, 319.

Atassi, M. Z. (1964). Nature, Lond., 202, 496.

Awad, E. S., Cameron, B. F. \& Kotite, L. (1963). Nature, Lond., 198, 1201.

Bates, R. G. (1964). Determination of pH, p. 74. New York: John Wiley and Sons Inc.

Beznak, M. (1948). Acta chem. scand. 2, 333.

Boardman, N. K. \& Adair, G. S. (1956). Nature, Lond., 177, 1078.

Boardman, N. K. \& Partridge, S. M. (1955). Biochem. J. $59,543$.

Bradley, D. E. (1959). Nature, Lond., 183, 941.

Brown, W. D. (1961). J. biol. Chem. 236, 2238.

Cameron, B. F. (1965). Analyt. Biochem. 11, 164.

Drabkin, D. L. (1945). Amer. J. med. Sci. 209, 268.

Edmundson, A. B. \& Hirs, C. H. W. (1962). J. molec. Biol. 5,663 .

George, P. \& Hanania, G. I. H. (1952). Biochem. J. 52, 517.

Hamoir, G. (1953). Nature, Lond., 171, 345
Hanania, G. I. H., Yeghiayan, A. \& Cameron, B. F. (1966). Biochem. J. 98, 189.

Huys, J. V. (1954). Arch. int. Physiol. 62, 296.

Keilin, J. \& Schmid, K. (1948). Nature, Lond., 162, 496.

Kendrew, J. C. (1950). Proc. Roy. Soc. A, 201, 62.

Kendrew, J. C. \& Parrish, R. G. (1957). Proc. Roy. Soc. A, 238, 305.

Kendrew, J. C., Parrish, R. G., Marrack, J. R. \& Orlans, E. S. (1954). Nature, Lond., 174, 946.

Kendrew, J. C. \& Pauling, P. J. (1956). Proc. Roy. Soc. A, 237, 255.

Kendrew, J. C. \& Trotter, I. F. (1954). Acta cryst. 7, 347.

Lawrie, R. A. (1951). Nature, Lond., 167, 802.

Lewis, U. J. \& Schweigert, B. S. (1955). J. biol. Chem. 214, 647.

Luginbuhl, W. H. (1960). Proc. Soc. exp. Biol., N.Y., 105, 504.

Matsuura, F. \& Hashimoto, K. (1955). Bull. Jap. Soc. sci. Fish. 20, 946.

Morgan, V. E. (1936). J. biol. Chem. 112, 557.

Perkoff, G. T., Hill, R. L., Brown, D. M. \& Tyler, F. H. (1962). J. biol. Chem. 237, 2820.

Porath, J. (1962). Advanc. Protein Chem. 17, 209.

Reichlin, M., Hay, M. \& Levine, L. (1963). Biochemistry, 2, 971.

Renard, S. (1953). Arch. int. Physiol. 61, 466.

Roche, J., Derrien, Y. \& Vieil, H. (1942). Trav. Soc. Chim. biol. 24, 1016.

Roche, J. \& Vieil, H. (1940). C.R. Acad. Sci., Paris, 210, 314.

Rossi-Fanelli, A. (1948). Science, 108, 15.

Rossi-Fanelli, A. \& Antonini, E. (1955). Arch. Biochem. Biophys. 58, 498.

Rossi-Fanelli, A. \& Antonini, E. (1957). In Symposium on Protein Structure, p. 140. Ed. by Neuberger, A. London: Methuen and Co. Ltd.

Rossi-Fanelli, A., Antonini, E. \& Povoledo, D. (1957). In Symposium on Protein Structure, p. 144. Ed. by Neuberger, A. London: Methuen and Co. Ltd.

Rossi-Fanelli, A., Cavallini, D. \& De Marco, C. (1954). Arch. Biochem. Biophys. 50, 496.

Rumen, N. M. (1959). Acta chem. scand. 13, 1542.

Theorell, H. (1932). Biochem. Z. 252, 1.

Theorell, H. \& de Duve, C. (1947). Arch. Biochem. 12, 113. 